[Bull. Agr. Chem. Soc. Japan, Vol. 24, No. 5, p. 481 489, 1960]

\title{
Studies on the Utilization of Levulinic Acid
}

\author{
Part II. Promotive Action of Acid Oximes on the Excretion \\ of Radioactive Cesium* \\ By Kazuhiko TAKamIYA** \\ Department of Agricultural Chemistry, Faculty of Agriculture, University of \\ Tokyo, Tokyo, Japan \\ Received December 9, 1959
}

\begin{abstract}
The single injection of levulinic acid oxime $(250 \mathrm{mg} / \mathrm{rat})$ or $\alpha$-ketoglutaric acid oxime (250 $\mathrm{mg} / \mathrm{rat}$ ) on rats, carrying radioactive cesium, promoted both urinary and fecal excretion of this radionuclide. The administration of levulinic acid oxime (sodium salt) decreased the cesium retention by liver. The administration of the oxime did not have influence on the urinary excretion of sodium and potassium in normal rats. The toxicity of the oxime was low. The $\operatorname{LD}_{50}$ of $\alpha$-ketoglutaric acid oxime was $3500 \mathrm{mg} / \mathrm{kg}$ (mice, intraperitoneally). (The $\mathrm{LD}_{50}$ of levulinic acid oxime has already been indicated as $2040 \mathrm{mg} / \mathrm{kg}$ (mice, intravenously) ${ }^{1 \text { ) }}$.
\end{abstract}

\section{INTRODUCTION}

In 1945, Hamilton ${ }^{23}$ observed approximately $100 \%$ absorption of radioactive cesium after ingestion, a low skeletal uptake, and a high accumulation in the soft tissues. Concerning the excretion of the administered radioactive elements, several experiments ${ }^{2-7)}$ have been carried out. The excretion of the cesium is slow, requiring approximately $7 \sim 10$ days to excrete $50 \sim 70$ per cent of the administered dose, and 64 days to excrete 99 per cent ${ }^{4)}$.

Radioactive cesium and strontium are known to be dangerous elements in the fission product. A relatively high accumulation of the strontium

\footnotetext{
* Some of the data have been presented at the meeting of the Agricultural Chemical Society of Japan, held at Tokyo, Sept. 27, 1958.

** Present address : Yoshimura Oil Chem. Co., Ltd., Toyonaka City, Osaka, Japan.

1) K. Takamiya, GANN, 50, 267 (1959); J. Antib., Ser. A, 9. 222 (1956).

2) J.G. Hamilton, MDDC 1062, Feb. 2, 1945; MDDC 1160 June 11, 1947; Radiology, 49, 325 343 (1947).

3) S.L. Hood and C.L. Comar, ORO.91 (1953) ; Arch. Biochem. and Biopbys., 45, 423 433 (1953).

4) K.G. Scott et al., MDDC 1275 (1947).

5) F.R. Mraz and H. Patrick, Federation Proc, 15, 565 (1956).

6) T. Watari, Nippon Acta Radiol., 1502 1507 (1958).

7) H. Yoshikawa et al., Ann. Rep. Co-ope. Res. (Radiation) M. Educ. (1957).
}

is observed in the skeleton, and the cesium is highly accumulated in the soft tissues ${ }^{3,8}$, especially in the muscle. The physiological effects of these elements remaining in the tissues shall not be overseen ${ }^{8}$, as each of them have a relatively long half-life, either physically or physiologically. Although studies to promote the excretion of radioactive strontium by administrating drugs, such as chelating agents, have been carried out by many authors, so far, there are few similar studies on th excretion of the radioactive cesium.

(a) Cesium, an alkali metal, has been reported to behave similarly to sodium, potassium, and rubidium. Mac. Leod and Snell ${ }^{9)}$, Love and Burch $^{102}$ observed the biological similarity of cesium to potassium in both bacteria and human erythrocytes, respectively. The effect of dietary potassium on cesium excretion was examined by Mraz and Patrick ${ }^{11}$, Williams and Patrick ${ }^{12}$,

8) T. Watari, Nippon Acta Radiol., 1480 1501 (1958).

9) R.A. Mac. Leod and E.E. Snell, J. Bacteriol, 59, 783 $792(1950)$.

10) W.D. Love and G.E. Burch, J. Lab. Clin. Med., 4.1, $351 \sim 362(1953)$.

11) F.R. Mraz and H. Patrick, Proc. Soc. Exptl. Biol. Med., 94, 409 412 (1957). 
and others. The increased excretion of the radioactive cesium was observed by administration of potassium ${ }^{11,127}$ (and sodium ${ }^{155}$ ). The supplementation of a simplified died with some feed stuff $\mathrm{s}^{5,13}$ (oat hulls, or others) increased the total excretion of cesium-134.

(b) Mraz and Patrick ${ }^{11,16)}$ fed rats with the following materials to increase their fecal excretion of cesium-134. The materials employed were vermiculite, bentonite, (alfalfa, beet pulp ${ }^{12}$, bone charcoal, and Amberlite IRC-50). The former two increased fecal excretion of cesium134, but the volume of the gut of rats was a limited factor.

(c) Suzuki ${ }^{17)}$ examined the effect of diuretics on cesium excretion, and found that they did not influence the retention of the radioactive element. Cesium is excreted by the kidneys, and parathyroid extract causes diuresis ${ }^{18}$. The following hormones have been examined as whether they could influence the retention or not. These hormones, such as cortisone ${ }^{12,18)}$, did not show a clear increase in cesium excretion. Machida et al. assumed aldosterone and DOCA ${ }^{14}$ ) to be most suitable for this purpose ${ }^{19}$. Other hormones examined ${ }^{203}$ were throxine, adrenaline, noradrenaline, insuline, tetrosterone, estradiol, and desoxycorticosterone ${ }^{21}$, etc. Vitamine $\mathrm{D}_{2}$ and glucose were also examined and were found to rather decrease the total excretion of cesium.

(d) A sodium and calcium salt of citric acid has been indicated by Ogawa to promote the excretion of radioactive elements, cesium-137, strontium-90, and zirconium-95.

12) L.G. Williams and H. Patrick, Arch. Biochem. and Bioploys, 70, 464 468 (1957).

13) F.R. Mrız and H. Patrick, J. Nutrition, 61, 535 546 (1957).

14) S.A. Threefoot, G.E. Burch and C.T. Ray, J, Lab. Clin. Med., 45, 313 322 (1955).

15) F.R. Mraz, M. Le Noir, J.J. Pinajian and H. Patrick, Arcb. Biocbem. Biopbys., 66, 177 182 (1957); E. Ogawa et al. Kilakanto Med. J., 8, 258 263 1958 .

16) F.R. Mraz and H. Parrick, Arch. Biocbem. and Biophys. 7 I, 121 $\sim 125(1957)$.

17) S. Suzuhi, Kitakanto Med. J., 8, 264 271 (1958).

18) F. Mraz. M. Le Noir, J. Pinazicin and H. Patrick, Arch. Biochem. and Biophys., 63, 73 76 (1956)

19) J. Machid,, Kitakanto Med. J., 8, 272 281 (1958).

20) J. Machidz, ibid., 8, 282 287 (1958).

21) R.I. Dorfman and A.M. Pott, Proc. Soc. Exptl. Biol. Med., 72, 702 (1949).
In the course of investigation of the biological effects of levulinic acid oxime, as a practical use of levulinic acid, which is an agricultural waste, the promotive action of the levulinic acid oxime, and $\alpha$-ketoglutaric acid oxime on cesium excretion was observed, and is described in this paper.

\section{EXPERIMENTAL}

Levulinic acid oxime ${ }^{22)}$, m.p. $97^{\circ} \mathrm{C}, \alpha$-ketoglutaric acid oxime ${ }^{23)}$, m. p. $140 \sim 141^{\circ} \mathrm{C}$ (dec.), or ethylenediamine tetraacetic acid (EDTA-2Na) was dissolved into physiological saline and neutralized to $\mathrm{pH} 7$ by sodium hydroxide or potassium hydroxide, respectively. Determination of the excreted cesium in urine of rats.

Each rat, weighing $170 \sim 270 \mathrm{~g}$ body weight, was administered $1 \mathrm{ml}$ of the solution $(\mathrm{pH} \mathrm{7})$ intraperitoneally, containing a radioactive cesium of $8.8 \mu \mathrm{c}$ of cesium-134, or $10 \mu \mathrm{c}$ of cesium-137. Urines were collected after every 24 hours and washed into a scaled flask, then filled up to $25 \mathrm{ml}$ with water. A $0.5 \mathrm{ml}$ aliquot of this test solution was evaporated to dryness on a stainlesssteel dish, and determined its count per minute (cpm) with a Geiger-Müller counter (Scientific Research Institute, Counter Model-100-ASA4). The distance from the mica window (mica: $2.3 \mathrm{mg} / \mathrm{cm}_{2}$ ) to the sample dish was $1.3 \mathrm{~cm}$ in length.

The mice were supplied a commercial type ration, Oriental compressed diet.

Determination of fecal excretion of the cesium.

The feces were collected every 24 hours. After digestion with concentrated nitric acid, the fecal solution was diluted to $50 \mathrm{ml}$. A $0.5 \mathrm{ml}$ aliquot of the diluted solution was counted its cpm after drying on the same sample dish. The distance from the mica window to the sample dish was $1.3 \mathrm{~cm}$ in length.

Determination of the accumulated cesium-131 in organs of a mouse.

The sample solution, $0.1 \mathrm{ml}(\mathrm{pH} \mathrm{7})$ containing $8.8 \mu \mathrm{c}$ of cesium-134, was injected intraperitoneally into mice weighing $15 \sim 18 \mathrm{~g}$ body weight. Sodium salt of levulinic acid oxime (5mg, or $10 \mathrm{mg}$ of the oxime per mouse) was injected daily into the peritoneal cavity 4 times, initiating 6 or 24 hours after administration of radioactive cesium. At 24 hours after the last injection, the mice were sacrificed and dissected to collect their kidneys,

22) P. Rischbieth, Bern, 2o, $(2670)$

23) M.M.E.E. Blaise and J. Gaule, Bull. Soc. chim. France, IV, 9, 457 . 
testis, livers, spleens, and muscle. Each organ was dried at $100^{\circ} \mathrm{G}$, and ashed at about $500 \sim 600^{\circ} \mathrm{C}$ to analyze for cesium-134. The distance from the mica window to the sample dish was $3.8 \mathrm{~cm}$ in length. Each group consisted with ten mice.

Determination of the excreted sodium and potassium in urine of rats.

Each rat of $270 \mathrm{~g}$ body weight was put to use. Urines were collected at every 24 hours, and the amount of excreted sodium and potassium were measured, respectively, with a "Lange Flammenphotometer Model 4". The commercial type ration, supplied, contained $0.474 \%$ of potassium and $0.300 \%$ of sodium.

\section{RESULTS}

Acute toxicity of $\alpha$-ketoglutaric acid oxime.

The solution containing each dose of $\alpha$-ketoglutaric acid oxime was administered intraperitoneally into mice, weighing $18 \sim 20 \mathrm{~g}$ body weight. The $\mathrm{LD}_{50}$ was $3.5 \mathrm{~g} / \mathrm{kg}$ (mice, intraperitoneally), as shown in Table I.

TABLE I. TOXICITY of $\alpha$-KeTOGLUTARIC ACID OXIME.

\begin{tabular}{|c|c|c|c|c|}
\hline \multirow{2}{*}{ dose $(\mathrm{g} / \mathrm{kg})$} & \multicolumn{4}{|c|}{$\begin{array}{c}=3.5 \mathrm{~g} / \mathrm{kg} \text { (mice, intraperitoneally) } \\
\text { Number of mice dying }\end{array}$} \\
\hline & 1st day & 2nd day & 3rd day & 9th da) \\
\hline 5 & $4 / 5$ & $5 / 5$ & $5 / 5$ & $5 / 5$ \\
\hline 3.5 & $1 / 5$ & $2 / 5$ & $2 / 5$ & $2 / 5$ \\
\hline 2 & $0 / 5$ & $0 / 5$ & $0 / 5$ & $0 / 5$ \\
\hline
\end{tabular}

Influence of oximes on the metabolism of radioactive cesiums.

The solution containing $8.8 \mu \mathrm{c}$ of cesium-134 (Cs-134-p) was neutralized with sodium hydroxide to $\mathrm{pH} \mathrm{7,} \mathrm{and} \mathrm{administered} \mathrm{intraperiton-}$ eally to each rat. The urinary excretion was maximum at the first 24 hours after administration, decreasing almost exponentially. After an elapse of several days, when daily excretion of cesium became approximately constant, the solution containing levulinic acid oxime (sodium salt) was injected into the peritoneal cavity. The increase of urinary excretion of radioactive cesium was observed within the following 48 hours (Fig. 1). The same effect was also observed with the injection of $\alpha$-ketoglutaric acid oxime (sodium salt), as shown in Fig. 2. As controls, physiological saline or EDTA (sodium salt) was injected. These reagent did not afford detectable increase of urinary excretion of cesium-134 (Fig. 2).

In the case of cesium-137 (Fig. 3), the same promotive effects of cesium excretion were caused by injection of levulinic acid oxime and $\alpha$ ketoglutaric acid oxime. Both fecal and urinary excretion of cesium-137 were increased by the administration of these two oximes. DOCA did not afford detectable influence on the excretion in case of a dose of $5 \mathrm{mg} / \mathrm{rat}$.

The influence of levulinc acid oxime (sodium salt) on cesium-134 retention by the organs was examined with mice. The administration of levulinic acid oxime decreased the cesium retention caused by the liver, but not in case of muscle, testis, spleen, and the kidneys. The results are shown in Fig. 4.

Influence of oximes on the urinary excretion of sodium and potassium by rats.

The urinary excretion of sodium and potassium by normal rats, carrying not the radioactive cesium, was about $80 \sim 120$ and $160 \mathrm{mg} /$ day, respectively. The injection of levulinic acid oxime (sodium salt) caused an increase in the urinary excretion of sodium, while no increase was observed in case of potassium. On the contrary, the injection of the oxime (potassium salt) increased potassium excretion, but did not have effect on sodium excretion. Also, injection of $\alpha$-ketoglutaric acid oxime (sodium salt) did not cause any increase in excretion of urinary potassium (Fig. 5), whereas it increased the sodium excretion.

\section{DISCUSSION}

The urinary excretion of radioactive cesium is indicated by several authors ${ }^{3 \sim 6,18)}$ to be many times as much as that of the fecal excretion. Furthermore, the daily excretion of urinary cesium was indicated to be independent of the total amount of daily urine. Thus, the effect of oximes on cesium excretion was first examined with rat's urine. The urinary excretion decreased daily almost exponentially. A single injection of sodium salt of levulinic acid oxime or $\alpha$ - 


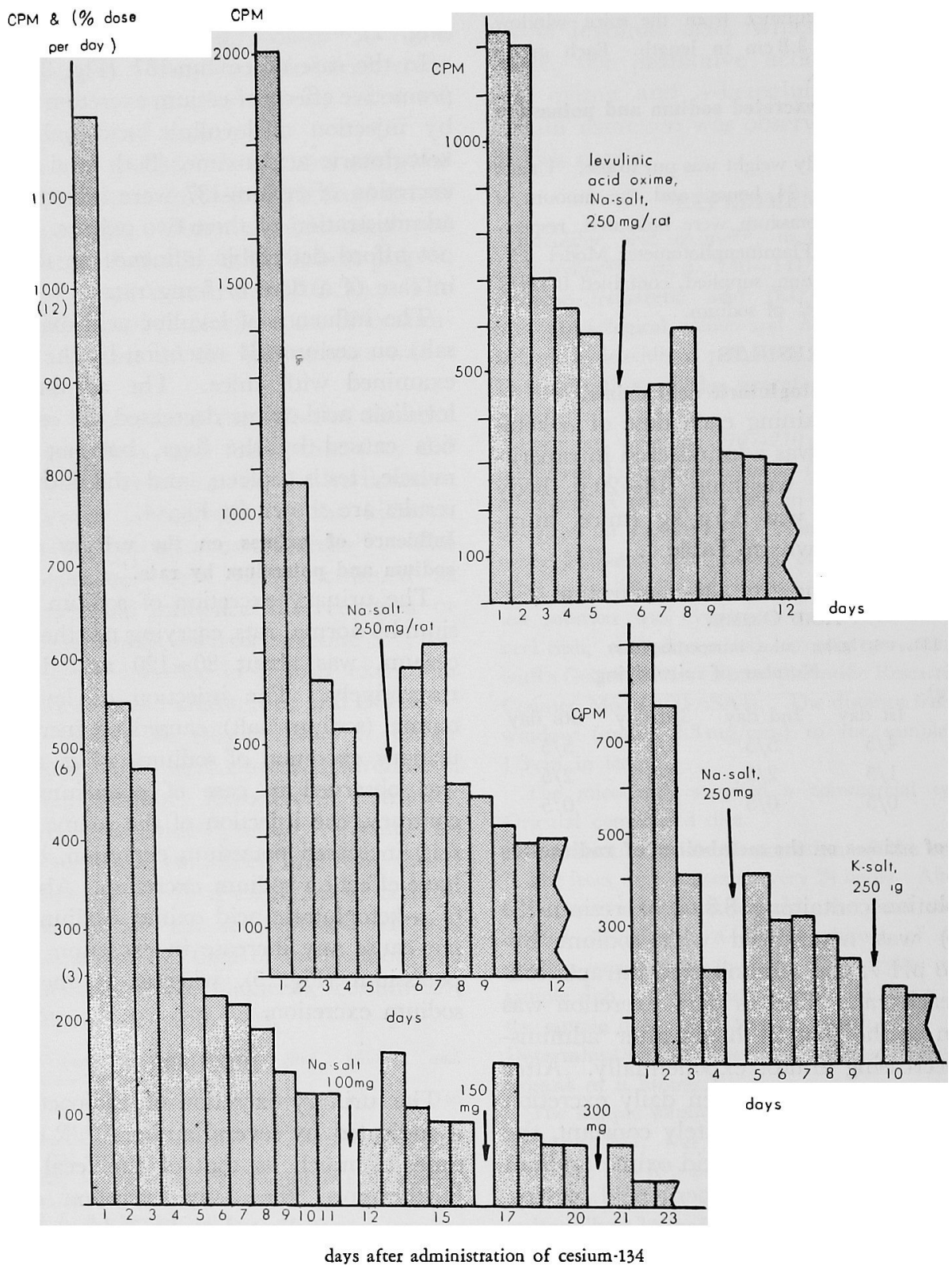

FIG. 1. Influence of Levulinic Acid Oxime on the Urinary Excretion of Cesium-134 by Rats. The excretory examinations were investigated several times with using about thirty rats. Figures 1, 2 and 3 show some typical patterns. 

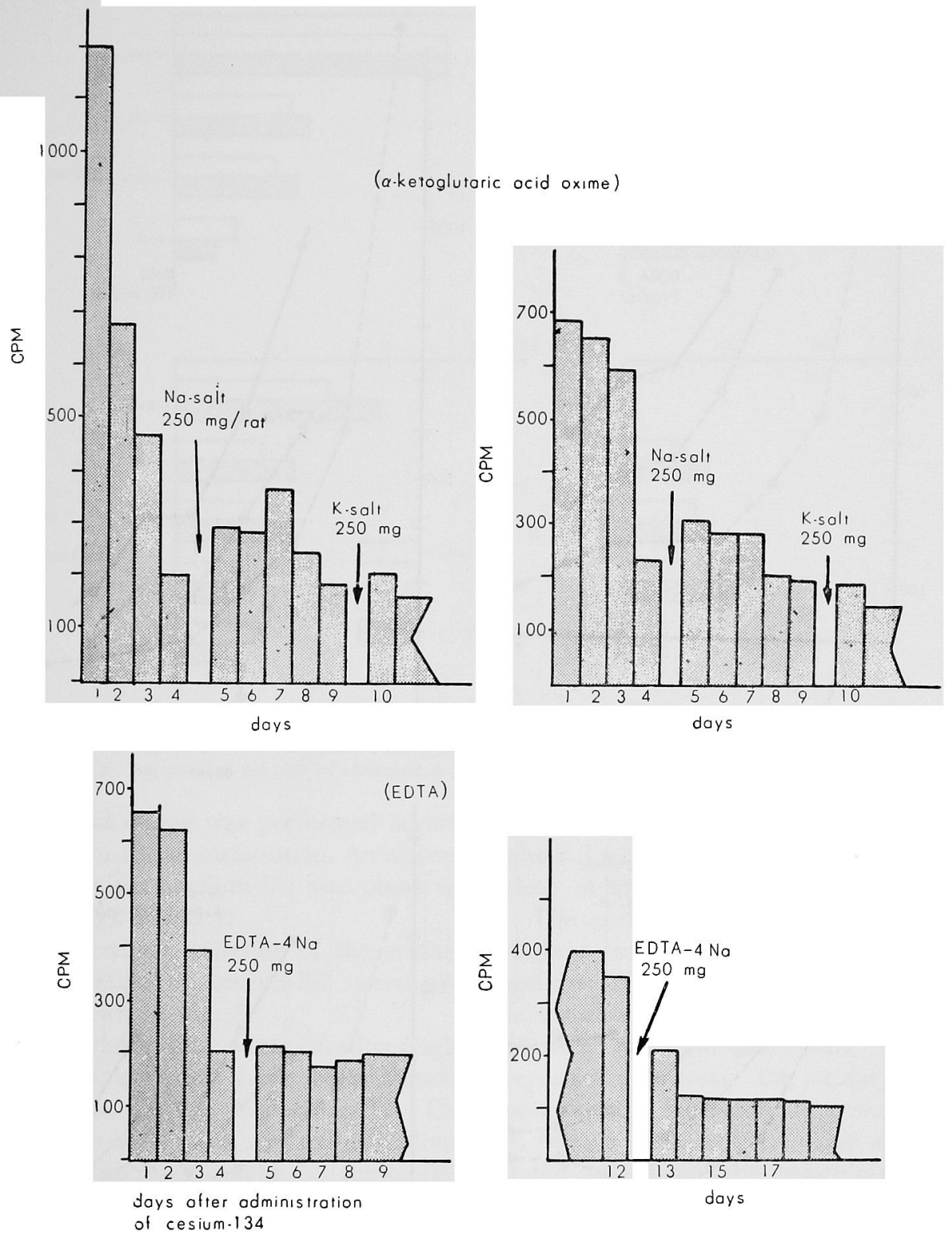

FIG. 2. Influences of $\alpha$-Ketoglutaric Acid Oxime or Ethylenediamine Tetraacetic Acid on the Urinary Excretion of Cesium-134 by Rats. 

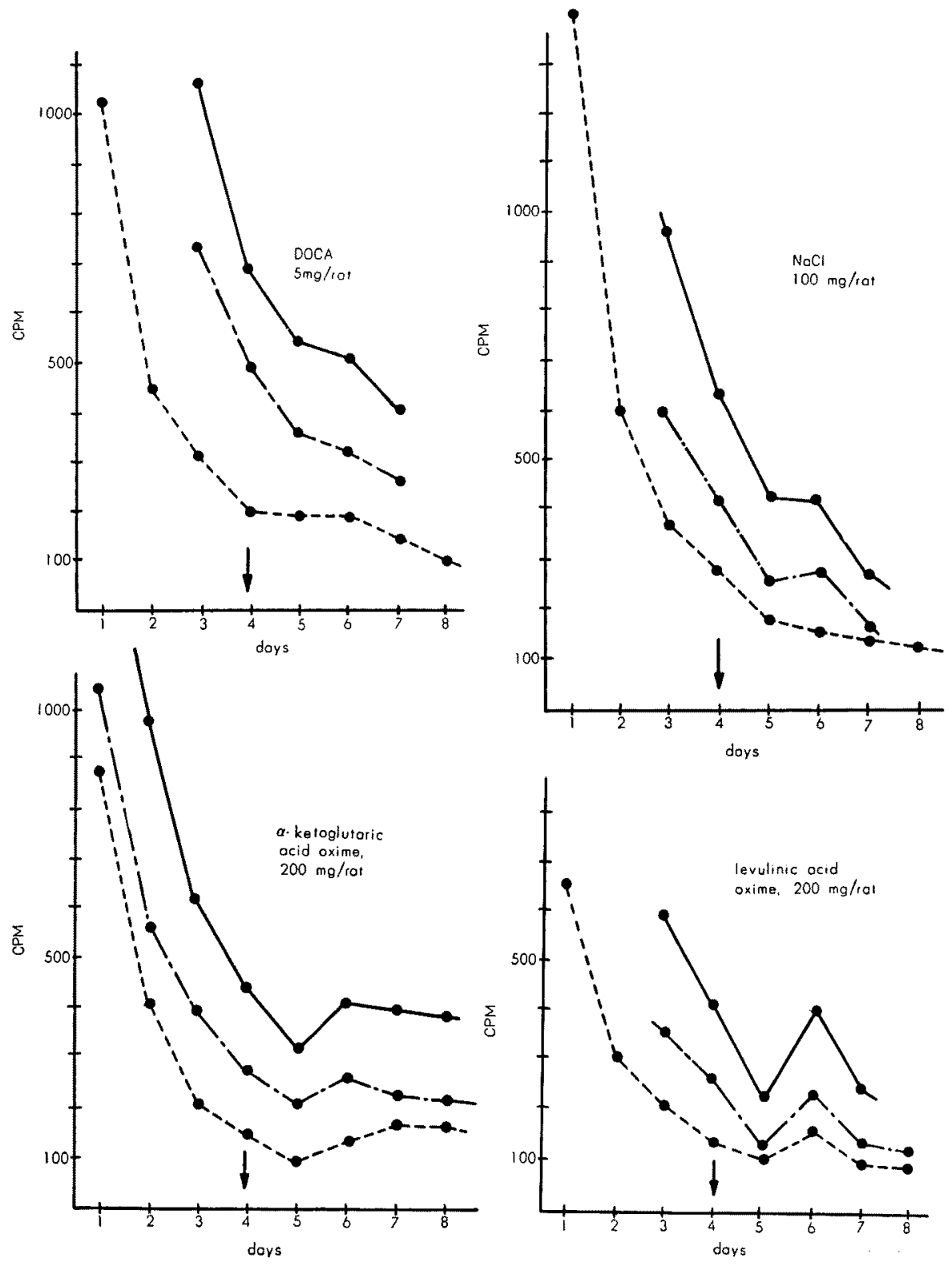

days after administration of cesium 137

FIG. 3. Influences on the Urinary Excretion of Cesium-137 by Rat.

- Toral excretion __ _ Fecal excretion _. U Urinary excretion 

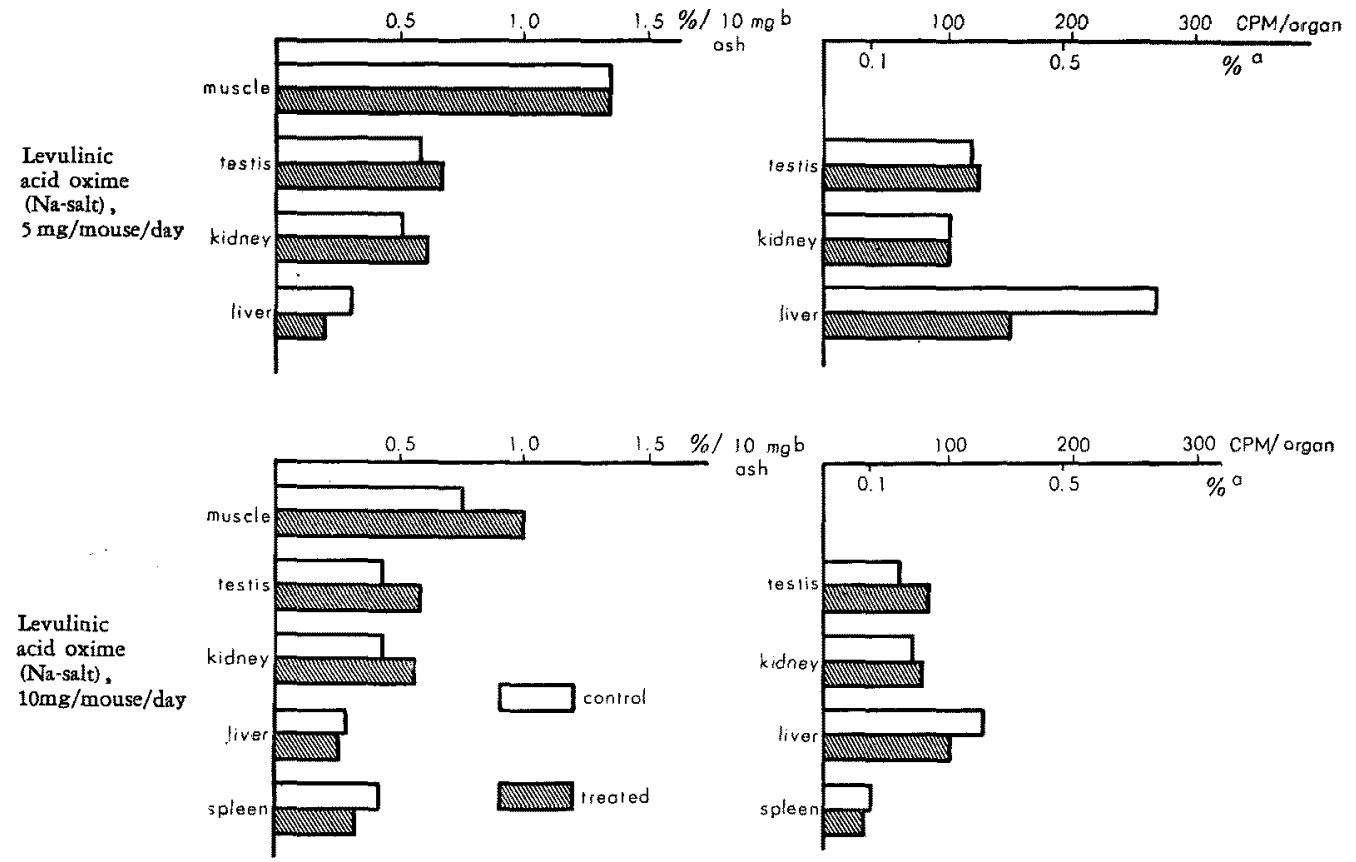

FIG. 4. Influence of Levulinic Acid Oxime (Na-salt) on the Metabolism of Cesium-134.

a : Expressed as per cent of the administered dose of Cs-134 per total ash of each organ.

b : Expressed as per cent of administered dose per $10 \mathrm{mg}$ ash of each organ.

ketoglutaric acid oxime was performed several days after cesium-134 administration. An increased excretion of uinary cesium-134 was observed, as shown in Figs. 1 and 2.

The same increased excretion of the urinary and fecal excretion of cesium-137 were also observed as shown in Fig. 3.

The findings that sodium administration might increase cesium excretion have been demonstrated by Mraz, Ogawa, and others ${ }^{15)}$. The promotive action of levulinic acid oxime (sodium salt) on cesium excretion might be responsible to the promotive action of sodium itself. Sodium chloride $(100 \mathrm{mg} / \mathrm{rat}$, containing about $60 \mathrm{mg} / \mathrm{rat}$ of sodium, Fig. 3), or EDTA solution (containing $250 \mathrm{mg} / \mathrm{rat}$ of EDTA-2 Na, $63 \mathrm{mg} / \mathrm{rat}$ of sodium, Fig. 2) was injected intraperitoneally into rats carrying radioactive cesium. However, they did not show distinct effects on cesium excretion. The promotive action of the oxime solution (containing $250 \mathrm{mg} / \mathrm{rat}$ of the oxime, about $1 \sim 1.6 \mathrm{mg} / \mathrm{rat}$ of sodium) may be due to that of the oxime itself.

The parathyroid extract has been reported to slightly increase cesium excretion with its consecutive injections, initiating just after cesium administration. Though it is still somewhat obscure, cortisone and other hormones are reported to increase the urinary excretion of potassium $^{24}$. Potassium and cesium are reported to behave similarly. Levulinic acid oxime was found to influence the cesium retention. Then, effects of the oximes on urinary excretion of sodium and potassium were investigated with normal rats, carrying not the radioactive cesium, as shown in Fig. 5. The intraperitoneal injec-

24) G.J. Hamwi and R.F. Goldberg., J. Am. Med. Assoc., I59, 1958 (1955);

F.A. Hartman and C.G. Toby, Endocrinology, 22, 207 (1938); D.J. Ingle et al., ibid., 39, $32(1946) ; 46,510(1950)$; J.P. Peters, J. Lancet, 73, 180 (1953). 


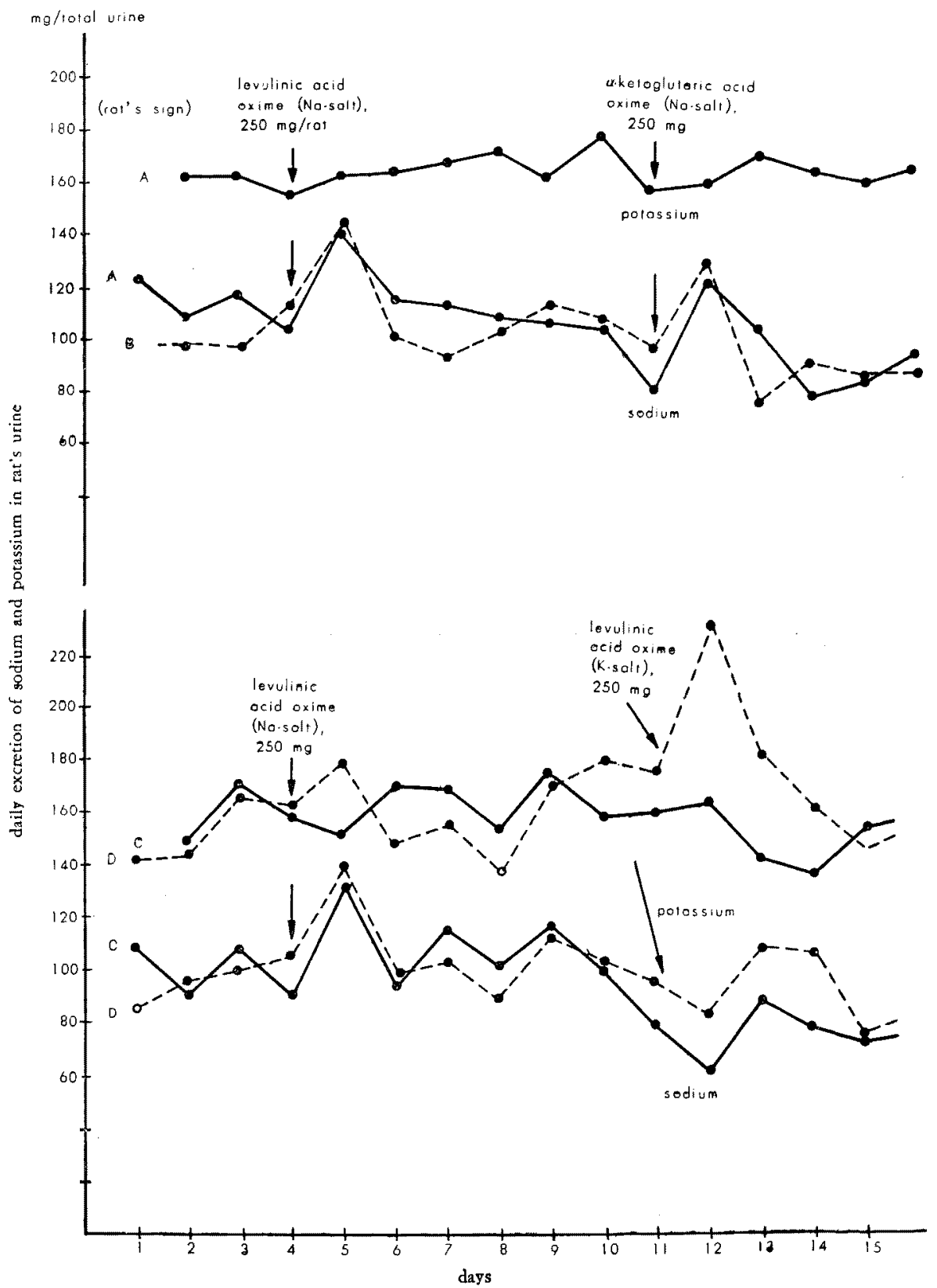

FIG. 5. Influence of Oximes on the Urinary Excretion of Sodium and Potassium by Rats, 
tion of levulinic acid oxime did not influence the urinary excretion of sodium and potassium in normal rats.

The sodium salt of levulinic acid oxime was injected into mice in order to measure the remaining cesium-134 in mice organs. The decrease of cesium-134 retention was observed in liver, but not in muscle, testis, spleen, and the kidneys. This point would be noteworthy in our future study.

The two oximes examined in this paper were almost non-toxic. $\mathrm{LD}_{50}$ of the oximes were
$2040 \mathrm{mg} / \mathrm{kg}$ (levulinic acid oxime, mice, intravenously), and $3500 \mathrm{mg} / \mathrm{kg}$ ( $\alpha$-ketoglutaric acid oxime, intraperitoneally), respectively.

Acknowledgements The author wishes to express his sincerest thanks to Prof. Y. Sumiki for his encouragement and guidance through these experiments. He is thankful to $\mathrm{Mr}$. Ko-ling Yeh and Miss H. Toyozumi, Departmen of Agricultural Chemistry, University of Tokyo, for their contributions in the course of this experiment.

[Bull. Agr. Chem. Soc. Japan, Vol, 24, No. 5, p. 489 496, 1960]

\title{
Betaine as a Growth Factor for Pediococcus soyae
}

Part VIII. Studies on the Activities of Bacteria in Soy Sauce Brewing

\author{
By Kenji Sakaguchi \\ Noda Institute for Scientific Research, Noda-shi, Chiba-ken \\ Received December 9, 1959
}

\begin{abstract}
Besides P-factor ${ }^{11}$, Pediococcus soyae $e^{2,3)}$ requires betaine (glycine-betaine) as a specific growth promotant. The maximal growth is obtained with the supplementation of both betaine and P-factor to the synthetic medium, while betaine only gives the half-maximal growth. When the organism is cultured in $18 \% \%$ salted media, the addition of both betaine and P-factor is essential for the occurrence of growth. Thus, betaine is requisite for Ped. soyae as a growth promoting factor and also as a factor bestowing the osmotelerant ability.
\end{abstract}

Pediococcus soyae is characterized by three eminent specificities, namely, by its acidsensitivity ${ }^{2)}$, by its osmotolerant character to grow even in $24 \sim 26 \%$ salted media ${ }^{1,2}$, and by its unique nutritional requirements ${ }^{1}$. This organism does not grow in the ordinary syntheic medium for lactic acid bacteria, and requires

1) Kenji Sakaguchi, This Bulletin, 23, 438, 443 (1959).

2) Kenji Sakaguchi, This Bulletin, 22, 353 (1958); 23, 22, 100 (1959); Rep. Node Inst. Sci. Res., 2, 40 (1958).

3) K. Yamazato and H. Iizuka, J. Agr. Chem. Soc. Japan, 33, 379. 383 (1958); J. Gen. Appl. Microbiol., 5, 58 (1959). two additional growth factors. One of them, which was provisionally named as P-factor in the preceding papers, is found to be included in partial hydrolysates of Hammersten's milk casein prepared with hydrochloric acid or various crystalline proteinases. The other, S-factor, is found to be present in Difco's yeast extract, beef extract, heart infusion broth, in soy sauce, and in the water extract of Aspergillus soyae mycelium. The maximal growth is, however, 